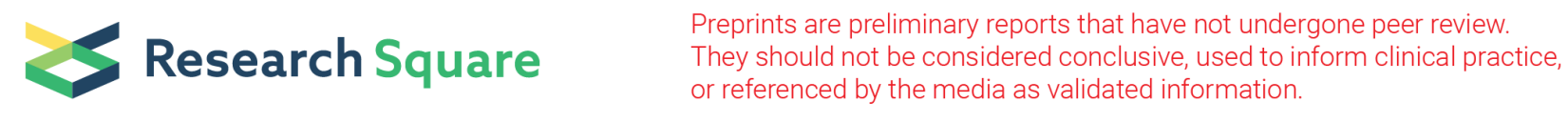

\title{
The pathological features of leukemic cells infiltrating the renal interstitium in chronic lymphocytic leukemia/small lymphocytic lymphoma from a large single Chinese center
}

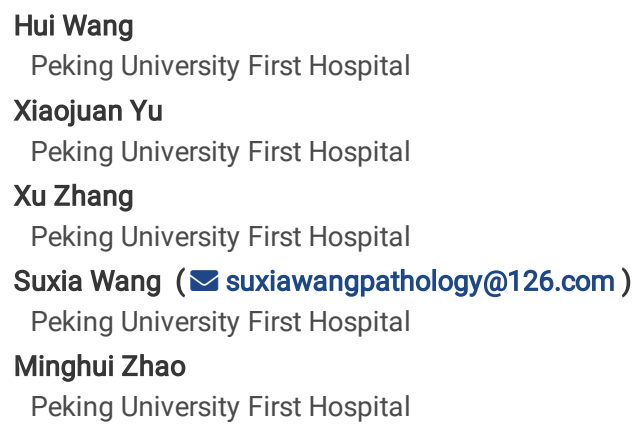

Keywords: Chronic lymphocytic leukemia/small lymphocytic lymphoma (CLL/SLL), infiltrating CLL cells, monoclonal immunoglobulins, pathological features, tubulointerstitial injury

Posted Date: March 16th, 2021

DOI: https://doi.org/10.21203/rs.3.rs-318647/v1

License: (c) (1) This work is licensed under a Creative Commons Attribution 4.0 International License. Read Full License 


\section{Abstract \\ Background}

Chronic lymphocytic leukemia/small lymphocytic lymphoma (CLL/SLL) is rare in Asians, and patients with CLL/SLL seldomly undergo kidney biopsy. The histopathological features and clinical relevance of tubulointerstitial injury in CLL/SLL have not been extensively charaterized. Hence, we attempted to describe the clinical characteristics, renal pathology and clinical outcome of a well-characterized population of CLL/SLL patients with CLL cell infiltration in the renal interstitium from a large single center in China.

\section{Methods}

Between January 1st, 2010 and September 31st, 2020, 31946 renal biopsy pathologies were performed at Peking University First Hospital, and 10 CLL/SLL patients with CLL cell infiltration in the renal interstitium were included. Complete clinical data were collected from these 10 patients, and renal specimens were examined by routine light microscopy, immunofluorescence and electron microscopy.

\section{Results}

The extent of the infiltrating CLL cells in patients with CLL/SLL varied among different patients and ranged from 10-90\% of kidney parenchyma. Six (60\%) of 10 patients presented with an extent of infiltrating CLL cells $\geq 50 \%$. Interestingly, we found that three patients (3/10,30\%) expressed monoclonal immunoglobulins in the infiltrating CLL cells, and special cytoplasmic crystalline structures were found in two of the three patients by electron micriscopy for the first time. Severe renal insufficiency ( $\mathrm{Scr} \geq 200 \mu \mathrm{mol} / \mathrm{L}$ ) was associated with $\geq 50 \%$ interstitial infiltration of CLL cells in the renal interstitium.

\section{Conclusions}

The findings confirmed that CLL cells infiltrating the renal interstitium can directly secrete monoclonal immunoglobulins, indicating that the interstitial infiltrating CLL cells probably cause renal injuriy directly by secreting monoclonal immunoglobulins in situ. This finding may prove a new clue to elucidate the pathogenetic mechanism of renal injury involved with CLL/SLL .

\section{Background}

Chronic lymphocytic leukemia/small lymphocytic lymphoma (CLL/SLL), the most common adult leukemia in the Western countries [1], is infrequent in Asians including China. This disease is characterized by the clonal expansion of CD5 + CD23 + B cells in peripheral blood, bone marrow, and the secondary lymphoid tissues. Extramedullary/extranodal manifestations of CLL/SLL are rare. The most commonly involved organs are the skin and central nervous system. Kidneys are rarely involved [2-3]. A study from the Mayo Clinic found a 7.5\% incidence of renal insufficiency at the time of CLL/SLL diagnosis in a cohort of over $2000 \mathrm{CLL} / \mathrm{SLL}$ patients. Importantly, the presence of kidney disease was independently associated with adverse patient outcomes in CLL/SLL [4], which emphasizes the importance of a detailed exploration of the mechanism of renal insufficiency in CLL/SLL.

In renal complications of CLL/SLL, the mechanism of renal insufficiency in such patients varies. Several studies have described the patterns of glomerular injury, which includes direct glomerular deposition of monoclonal proteins, cryoglobulins, and immune complexes [5-6]. However, the renal tubulointerstitial injury was described simply. Previous studies related to CLL cell infiltration of the kidney have been either case reports with a single patient or small case series [5-13], with the largest report including 6 patients [5]. In these studies, the histopathological features of CLL cells infiltrating the renal interstitium were not described in detail, and the mechanism of renal injury with CLL cell infiltration remained unclear.

In this study, we attempted to describe the clinical characteristics, renal pathology and clinical outcome of a well-characterized population of CLL/SLL patients with CLL cell infiltration in the renal interstitium from a large single center at Peking University First Hospital in China. We investigated the pathological features of infiltrating CLL cells in the renal interstitium in detail and tried to explore the possible pathogenesis of renal injury in association with CLL/SLL.

\section{Methods}

\section{Patients}

Between January 1st, 2010 and September 31st, 2020, 31946 real biopsy pathologies were performed at Peking University First Hospital. Finally, after screening of the renal pathology database, 10 patients with CLL cell infiltration in the renal interstitium were included. CLL/SLL was diagnosed according to the WHO classification [14-15]. The diagnosis of CLL requires the presence of at least $5 \times 10^{9} \mathrm{~B}$ lymphocytes/L in the peripheral blood over $>3$ months, with evidence of monoclonality (CD5, CD19, CD20, CD23). CLL is distinguishable from SLL by its leukemic appearance. The definition of SLL requires a histological analysis of lymph node biopsy. CLL/SLL of all 10 patients was confirmed before or at the time of the kidney biopsy.

Informed consent was obtained from each patient. The research was in compliance with the Declaration of Helsinki and approved by the ethics committee of Peking University First Hospital. 
Baseline clinical data, including age, sex, medical history, CLL clinical course, CLL-involved organs, proteinuria, hematuria, serum creatinine, complete blood test, serum/urine immunofixation electrophoresis, and treatment, were obtained from the clinical records. Patients were followed up in the outpatient clinic or by telephone.

\section{Renal histopathology assessment}

Renal biopsy was examined by standard direct immunofluorescence, light microscopy and electron microscopy. For light microscopy, biopsy specimens were stained with hematoxylin-eosin, periodic acid Schiff, Masson trichrome, and Jones methenamine silver. For immunofluorescence, 3-micron cryostat sections were stained with polyclonal fluorescein isothiocyanate-conjugated antibodies of the $\operatorname{lgG}$, IgM, IgA, C3, C1q, kappa light chain, lambda light chain and IgG subclasses. Electron microscopy was performed as per routine clinical practice. Immunohistochemical staining for CD3, CD 5, CD20, CD23, Cyclin D1, CD43, TdT, CD10, and BCL6 was performed on renal biopsies to assess CLL/SLL involvement. Two pathologists specializing in the evaluation of renal pathology separately evaluated the renal biopsies. All cases were also reviewed by hematopathologists specializing in review of lymphoid malignancy. Differences in diagnosis between the two pathologists were resolved by rereviewing the biopsies to reach a consensus.

\section{Immunoelectron microscopy}

Immunogold labeling was further performed according to the methods described by previous studies [16]. Eighty-nm-thick resin-embedded sections were attached to the surface of a carbon-coated support film grid and blocked with $2 \%$ bovine serum albumin in $0.01 \mathrm{M}$ phosphate buffer saline, pH 7.4 , saline for 5 min at $37^{\circ} \mathrm{C}$, followed by incubation overnight at $4^{\circ} \mathrm{C}$ using an extensive panel of antibodies such as polyclonal rabbit anti-human kappa and lambda light chain (1:1000; Dako, Carpenteria, CA) and monoclonal mouse anti-human IgG1, IgG2, IgG3, and IgG4 (1:100; Southern Biotech, Birmingham, AL). Then, after incubation with a gold-conjugated secondary antibody (colloid gold particles with a diameter of $10 \mathrm{~nm}$ ) for $1 \mathrm{~h}$, the grid was ready for observation using a transmission electron microscope. Negative controls were prepared by omitting the primary antibody.

\section{Statistical analysis}

Statistical software SPSS 13.0 (SPSS, Chicago, IL, USA) was used. Descriptive statistics of the baseline characteristics were calculated. Continuous data are expressed as the mean \pm s.d. or median with the range. Categorical variables are presented as proportions. Correlation between pathological characteristics in the kidney interstitium and serum creatinine at renal biopsy were performed using Fisher's exact test.

\section{Results}

\section{Demographic and baseline clinical data}

The clinical features at biopsy are presented in Table 1. Five males (50\%) and 5 females (50\%) were enrolled. The mean age was $64.4 \pm 4.9$ (range $58-73$ ) years old. CLL/SLL was diagnosed before kidney biopsy in 5/10 cases, with a mean interval of 23.8 months (range 2-60 months). Four patients were biopsied for acute kidney disease, two for acute kidney injury and four for proteinuria. The mean serum creatinine at renal biopsy was $276.6 \pm 192.3 \mu \mathrm{mol} / \mathrm{L}$ (range: $95-616 \mu \mathrm{mol} / \mathrm{L}$ ). The median proteinuria was $3.5 \mathrm{~g} / 24 \mathrm{hr}$ (range: $0.48-12.8$ ), with a mean serum albumin of $33.6 \pm 9.1 \mathrm{~g} / \mathrm{L}$. Seven patients (70\%) had microscopic hematuria. All patients underwent bone marrow biopsy, and eight patients (80\%) showed CLL/SLL cell bone marrow infiltration. Eight patients (80\%) had multiple enlarged lymph nodes, and all of them had lymph node biopsy with the definition of SLL. One patient had splenomegaly. Six patients $(60 \%)$ had positive serum monoclonal immunoglobulins, including 3 patients with $\lg \mathrm{M \kappa}, 2$ patients with $\lg \mathrm{GK}$ and 1 patient with $\lg \mathrm{M} \lambda$, respectively. 
Table 1

The clinical features of CLL/SLL patients

\begin{tabular}{|c|c|c|c|c|c|c|c|c|c|c|c|c|c|}
\hline Case & Age/sex & $\begin{array}{l}\text { Time } \\
\text { (months) }\end{array}$ & $\begin{array}{l}\text { Scr } \\
(\mu \mathrm{mol} / \mathrm{L})\end{array}$ & $\begin{array}{l}\text { UTP } \\
( \\
\mathrm{g} / 24 \\
\mathrm{hr})\end{array}$ & Mlg & Cryo & $\begin{array}{l}\text { C3 } \\
(g / L)\end{array}$ & $\begin{array}{l}\text { C4 } \\
(g / L)\end{array}$ & ER-IO & Treatment & $\begin{array}{l}\text { F. time } \\
\text { (months) }\end{array}$ & $\begin{array}{l}\text { Renal } \\
\text { outcome }\end{array}$ & CLL/S \\
\hline 1 & $67 / M$ & 2 & 118 & 10.35 & $\lg M \lambda$ & Trace & $0.57 \downarrow$ & 0.12 & LN & CYC, CsA & 56 & $\begin{array}{l}\text { Not } \\
\text { recovery }\end{array}$ & Stable \\
\hline 2 & $66 / M$ & 0 & 616 & 0.80 & Negative & Trace & 0.63 & 0.26 & $\begin{array}{l}\text { LN, } \\
\text { BM }\end{array}$ & Supportive & 52 & $\begin{array}{l}\text { ESRD } \\
\text { (never } \\
\text { recovered) }\end{array}$ & Stable \\
\hline 3 & $58 / F$ & 0 & 95 & 1.15 & $\operatorname{lgGK}$ & Negative & 0.92 & 0.21 & BM & $\begin{array}{l}\text { COP, } \\
\text { Rituximab } \\
\text { Ibrutinib }\end{array}$ & 32 & $\begin{array}{l}\text { Completely } \\
\text { recovery }\end{array}$ & Impro' \\
\hline 4 & $58 / F$ & 0 & 174 & 0.48 & $\lg \mathrm{Mk}$ & Negative & $0.48 \downarrow$ & $0.05 \downarrow$ & LN,BM & RFC & 31 & $\begin{array}{l}\text { Completely } \\
\text { recovery }\end{array}$ & Stable \\
\hline 5 & $66 / F$ & 60 & 570 & 0.87 & Negative & NA & 0.72 & 0.34 & $\begin{array}{l}\text { LN, } \\
\text { Spleen } \\
\text { BM }\end{array}$ & $\begin{array}{l}\text { CHOP, } \\
\text { Ibrutinib }\end{array}$ & 15 & $\begin{array}{l}\text { Partial } \\
\text { recovery }\end{array}$ & Stable \\
\hline 6 & $62 / \mathrm{M}$ & 36 & 118 & 4.27 & $\operatorname{IgGK}$ & $\operatorname{lgGK}$ & $0.57 \downarrow$ & $0.09 \downarrow$ & LN,BM & $\begin{array}{l}\text { COP, } \\
\text { Ibrutinib }\end{array}$ & 8 & $\begin{array}{l}\text { Completely } \\
\text { recovery }\end{array}$ & Satab \\
\hline 7 & $68 / F$ & 18 & 456 & 2.17 & Negative & NA & 0.81 & 0.16 & LN, & Prednisone & 6 & $\begin{array}{l}\text { Partial } \\
\text { recovery }\end{array}$ & Impro' \\
\hline 8 & $59 / F$ & 0 & 377 & 0.59 & $\lg \mathrm{Mk}_{\mathrm{k}}$ & Type II & $0.46 \downarrow$ & $0.02 \downarrow$ & LN,BM & $\begin{array}{l}\text { PE for } \\
\text { TMA }\end{array}$ & 33 & $\begin{array}{l}\text { Partial } \\
\text { recovery }\end{array}$ & Progre \\
\hline 9 & $73 / \mathrm{M}$ & 3 & 161 & 1.44 & Negative & Negative & 0.76 & 0.20 & BM & Supportive & 2 & $\begin{array}{l}\text { Not } \\
\text { recovery }\end{array}$ & Stable \\
\hline 10 & $67 / M$ & 0 & 221 & 12.8 & $\lg \mathrm{MK}$ & $\lg М к$ & $0.244 \downarrow$ & $0.06 \downarrow$ & LN,BM & Ibrutinib & 1 & $\begin{array}{l}\text { Partial } \\
\text { recovery }\end{array}$ & Stable \\
\hline
\end{tabular}

Notes: Time: time from diagnosis of CLL/SLL to renal biopsy; Scr: serum creatinine at renal biopsy

Abbreviations: UTP: urine total protein; Mlg: monoclonal immunoglobulin deteremined by serum/urine immunofixation electrophoresis; Cryo: cryoglobulinemi ER-IO: extra-renal involved organs; F.time: follow up time; LN: lymph node; BM: bone marrow; CYC: cyclophosphamide; CsA: cyclosporine; ESRD: end stage rer disease; COP: cyclophosphamide, vincristine, and prednisone; RFC: rituximab, fludarabine and cyclophosphamide; CHOP: cyclophosphamide, doxorubicin, vincristine and prednisone; PE: plasma exchange; TMA: thrombotic microangiopathy

\section{Renal biopsy findings and characteristics of CLL cell infiltration in the renal interstitium}

Table 2 summarizes the kidney biopsy pathology and characteristics of the interstitial infiltrating CLL cells. All of these patients presented varying degrees of monotypic small lymphocyte infiltration in the renal interstitium. These changes expanded the interstitium at the expense of the tubular structures, the peritubular capillaries, and less frequently the glomeruli (Fig. 1). Immunohistochemical staining showed the monotypic lymphocyte cells stained positive for CD20, CD5 and CD23 and negative for Cyclin D1, CD10, CD138 and CD68 (Fig. 1). 
Table 2

The kidney biopsy pathology and characteristics of the interstitial infiltrating CLL cells

\begin{tabular}{|c|c|c|c|c|c|c|c|}
\hline & Glomerular & & & Interstitium & & & \\
\hline Case & Light microscopy & Immunofluores-cence & $\begin{array}{l}\text { Electron } \\
\text { microscopy }\end{array}$ & $\begin{array}{l}\text { Light } \\
\text { microscopy }\end{array}$ & & & $\begin{array}{l}\text { Immuno } \\
\text { rescence }\end{array}$ \\
\hline & Injury pattern & & $\begin{array}{l}\text { Electron dense } \\
\text { deposits }\end{array}$ & $\begin{array}{l}\text { The extent } \\
\text { of infiltrate } \\
\text { CLL cells }\end{array}$ & $\begin{array}{l}\text { Nodular } \\
\text { pattern } \\
\text { formation }\end{array}$ & Granulomatous & \\
\hline 1 & Membranous nephritis & $\begin{array}{l}\operatorname{lgG}++, \mathrm{C} 3+ \\
\mathrm{C} 1 \mathrm{q}+\end{array}$ & $\begin{array}{l}\text { Subepithelial } \\
\text { deposits }\end{array}$ & $10 \%$ & No & No & Negative \\
\hline 2 & Mininal change & Negative & No deposits & $90 \%$ & Yes & No & Negative \\
\hline 3 & $\begin{array}{l}\text { Focal mesangial and } \\
\text { endocapillary } \\
\text { proliferative } \\
\text { glomerulonephritis }\end{array}$ & C3++ & $\begin{array}{l}\text { Mesangial and } \\
\text { hump-like } \\
\text { subepithelial } \\
\text { deposits }\end{array}$ & $10 \%$ & No & No & Negative \\
\hline 4 & $\begin{array}{l}\text { Membranoproliferative } \\
\text { glomerulonephritis }\end{array}$ & $\lg \mathrm{G}++, \lg \mathrm{M}+++, \mathrm{C} 3+, \mathrm{C} 1 \mathrm{q}+, \mathrm{K}++, \lg \mathrm{G} 1++, \lg \mathrm{G} 2++$ & $\begin{array}{l}\text { Subendothelial } \\
\text { deposits with } \\
\text { microtubule } \\
\text { formation }\end{array}$ & $10 \%$ & No & No & Negative \\
\hline 5 & Mininal change & Negative & No deposits & $90 \%$ & Yes & Yes & Negative \\
\hline 6 & $\begin{array}{l}\text { Membranoproliferative } \\
\text { glomerulonephritis }\end{array}$ & $\begin{array}{l}\lg \mathrm{G}++, \mathrm{C} 3++, \mathrm{C} 1 \mathrm{q}+, \mathrm{K}++ \\
\lg \mathrm{G} 1++\end{array}$ & $\begin{array}{l}\text { Subendothelial } \\
\text { and } \\
\text { subepithelial } \\
\text { deposits with } \\
\text { microtubule } \\
\text { formation }\end{array}$ & $70 \%$ & Yes & No & $\begin{array}{l}\mathrm{K++} \\
\mathrm{IgG} 1++\end{array}$ \\
\hline 7 & $\begin{array}{l}\text { Focal mesangial and } \\
\text { endocapillary } \\
\text { proliferative } \\
\text { glomerulonephritis }\end{array}$ & $\mathrm{C} 3++$ & $\begin{array}{l}\text { Mesangial and } \\
\text { hump-like } \\
\text { subepithelial } \\
\text { deposits }\end{array}$ & $50 \%$ & Yes & No & Negative \\
\hline 8 & $\begin{array}{l}\text { Mesangial } \\
\text { proliferative } \\
\text { glomerulonephritis } \\
\text { and thrombotic } \\
\text { microangiopathy }\end{array}$ & C3++ & $\begin{array}{l}\text { Mesangial and } \\
\text { Subendothelial } \\
\text { deposits }\end{array}$ & $50 \%$ & Yes & No & Negative \\
\hline 9 & $\begin{array}{l}\text { Glomerular } \\
\text { hypertrophy }\end{array}$ & Negative & No deposits & $20 \%$ & No & No & Negative \\
\hline 10 & $\begin{array}{l}\text { Membranoproliferative } \\
\text { glomerulonephritis }\end{array}$ & $\lg M++, \mathrm{K}++$ & $\begin{array}{l}\text { Subendothelial } \\
\text { and mesangial } \\
\text { deposits with } \\
\text { microtubule } \\
\text { formation }\end{array}$ & $50 \%$ & Yes & No & $\begin{array}{l}\operatorname{lgM}++ \\
\mathrm{K}++\end{array}$ \\
\hline
\end{tabular}

The extent of infiltrating CLL cells was diverse between different patients, from 10-90\%. Six patients (60\%) presented interstitial CLL cell infiltration $\geq 50 \%$. Vaguely nodular pattern can be seen among infiltrating CLL cells of these 6 patients, in which prolymphocytes and paraimmunoblasts were detected (Fig. 1). Notably, of the 6 patients, two patients (Case 6 and Case 10) showed monoclonal immunoglobulin expression in the renal interstitium by immunofluorescence ( $\mathrm{IgG} 1 \mathrm{k}$ for Case 6 and IgMk for Case 10), which was identical to that of the serum immunoglobulin paraprotein. By electron microscopy observation, special crystalline structures were found in the cytoplasm of infiltrating CLL cells in two patients (Case 2 and Case 6). In Case 6, a fuzzy filament structure was observed in these crystalline structures (Fig. 2), and IgG1 $\mathrm{K}$ expression was detected in these crystals by immunoelectron microscopy (Fig. 2). In another patient (Case 2), although immunofluorescence showed no specific interstitial deposits, rhombic crystals were also found in the cytoplasm of infiltrating CLL cells, and monoclonal $\lambda$ was expressed in these crystals by immunoelectron microscopy (Fig. 3). In brief, three patients (30\%) expressed monoclonal immunoglobulins in the infiltrating CLL cells and the cytoplasmic crystals were identified in two patients (20\%). In addition, non-necrotic epithelioid granulomas were found in one patient (Case 5, Fig. 1). Periodic acid Schiff and Grocott staining revealed no microorganisms. Immunofluorescence showed no specific interstitial deposits.

Eight patients (80\%) also had concurrent glomerular diseases. Membranoproliferative glomerulonephritis (MPGN) was present in 3 patients (Cases 4,6 and 10). All of them showed glomerular deposits composed of monoclonal immunoglobulins (IgMk in 2 cases, IgGk in one case) by immunofluorescence. Two patients exhibited patterns of endocapillary proliferative glomerulonephritis (Cases 3 and 7). The ultrastructural findings of massive hump-like subepithelial deposits indicated bacterial infection-associated glomerulonephritis in these two patients. The other glomerular diseases included one patient of phospholipase A2 receptor-negative membranous nephropathy (Case 1), one thrombotic microangiopathy (Case 8), and one obesity-associated glomerular hypertrophy (Case 9). 
Next, we assessed whether pathological characteristics in the kidney interstitium affected renal function at renal biopsy. There were 5 patients whose Scr was $\geq 200 \mu \mathrm{mol} / \mathrm{L}$ at renal biopsy and 5 patients with $<200 \mu \mathrm{mol} / \mathrm{L}$. All 5 patients with $\mathrm{Scr} \geq 200 \mu \mathrm{mol} / \mathrm{L}$ presented CLL cell infiltration $\geq 50 \%$ with nodular pattern formation in the interstitium $(5 / 5,100 \%)$ compared with 1 patient with $\mathrm{Scr}<200 \mu \mathrm{mol} / \mathrm{L}(1 / 5,20 \%)$ who showed infiltration $\geq 50 \%$ with nodular pattern formation. That is, patients with $\mathrm{Scr} \geq 200 \mu \mathrm{mol} / \mathrm{L}$ were more likely to have intense CLL cell infiltration with nodular pattern formation $(P=0.048)$. No significant differences were found between Scr at renal biopsy and other pathological characteristics in the kidney interstitium, such as the expression of monoclonal immunoglobulins in CLL cells and granulomatous formation (data not shown).

\section{Discussion}

CLL/SLL is extremely rare in Asians compared with persons of predominately European descent [1]. Unlike plasma cell dyscrasias, in which kidney biopsy is routinely performed to evaluate unexplained renal insufficiency [17], patients with CLL/SLL rarely undergo kidney biopsy because CLL/SLL usually follows an indolent course. In the series from the Mayo Clinic [5], of all the CLL/SLL patients studied, only $1.2 \%$ underwent kidney biopsy. The low rate of kidney biopsy is a limiting factor in our understanding of CLL/SLL-associated kidney disease. Here, we attempted to better describe the pathological features of CLL cells infiltrating in the renal interstitium of CLL/SLL patients with in a Chinese cohort. In particular, we found that infiltrating CLL cells expressed monoclonal immunoglobulins with crystal formation for the first time. These pathological features suggested that in situ secretion of monoclonal immunoglobulins by renal infiltrating CLL cells may participate the pathogenetic mechanism of renal injury in patients with CLL/SLL.

Renal interstitial infiltration is a frequent finding in autopsy series of CLL/SLL patients, and the extent of infiltrating CLL cells was estimated to be between $10 \%$ and $90 \%$ in previous reports [5-13]. However, the specific role of these infiltrating CLL cells in the development and progression of renal disease is equivocal. In our study, severe renal failure (Scr $\geq 200 \mu \mathrm{mol} / \mathrm{L}$ ) at renal biopsy was associated with intense CLL cell infiltration ( $\geq 50 \%)$ and nodular pattern formation. Although the sample size was not sufficiently large in our study, the significant association indicated that infiltrating CLL cells might affect the severity of kidney failure. To date, the mechanism of renal injury with CLL cell infiltration has not been clearly established but has been hypothesized to involve tubular/microvascular compression causing intrarenal obstruction in addition to an infiltration-associated inflammatory/cytokine response [5-6]. For example, diffuse infiltration likely compresses the renal tubules and microvasculature, resulting in intrarenal obstruction and ischemia. Alternatively, cytokines such as IL-1, IL-6, TNF- $\alpha$, and TGF- $\beta$, secreted directly by lymphoma cells, may lead to tubular injury and interstitial fibrosis [18]. Interestingly, we found that infiltrating CLL cells expressed monoclonal immunoglobulins with crystal formation for the first time, which suggested that CLL cells are probably directly involved in local injuries by secreting monoclonal immunoglobulins in situ. The presence of serum monoclonal immunoglobulin has been shown to worsen the prognosis of CLL/SLL patients [19-20]. Although it was not clear whether monoclonal immunoglobulins secreted by local infiltrating CLL cells can enter the blood circulation, the presence of cytoplasic crystal formation was sufficient to cause cell injury. For example, when crystals of monoclonal light chains deposit in the cytoplasm of proximal tubules, patients exhibit features of proximal tubular dysfunction called light chain proximal tubulopathy (LCPT) [21]. Therefore, the injury induced by monoclonal immunoglobulins secreted by CLL cells in the renal interstitium should be considered.

Moreover, nodular pattern was seen among infiltrating CLL cells in the renal interstitium and prolymphocytes and paraimmunoblasts were detected. A histologic hallmark of CLL/SLL, when it involves lymph nodes, is the formation of proliferation centers characterized by nodular expansions of prolymphocytes and paraimmunoblasts admixed with small lymphocytes. Our study indicated that this organizational structure also formed in the renal interstitium. Recent studies suggest a correlation between a more aggressive disease and proliferation centers in both lymph nodes and bone marrow and suggest that extended proliferation centers may represent a new prognostic marker of CLL/SLL [22-24]. These findings were consistent with our study showing that nodular pattern were associated with severe renal failure ( $\mathrm{Scr} \geq 200 \mu \mathrm{mol} / \mathrm{L})$ at renal biopsy. An increasing body of data suggests that proliferation centers are important sites of cell proliferation and the accumulation of genomic aberrations [25]. Proliferation center cells express proteins associated with increased levels of cell proliferation-related markers, including Ki67, CD23, CD71, MUM1/IRF-4 and cyclin D1 [26-27]. Interactions between CLL and accessory cells within proliferation centers are critical for providing growth and survival signals to CLL B cells, inducing their proliferation, promoting differentiation into either an antibody-secreting cell or a memory cell, or maintaining a nonsecreting blast [28]. Our study indicated that the kidney microenvironment may play a central role in the pathogenesis of CLL. More therapeutic efforts need to be made to disrupt the crosstalk between CLL cells and signals of the microenvironment in the kidney interstitium in the future.

\section{Conclusions}

In summary, we attempted to better describe the pathological features of CLL/SLL patients with CLL cell infiltration in the renal interstitium in a Chinese cohort. Notably, monoclonal immunoglobulins were secreted by CLL cells infiltrating the renal interstitium with crystal formation, indicating that these cells are probably directly involved in local injuries by secreting monoclonal immunoglobulins in situ. This finding may prove a new clue to elucidate the pathogenetic mechanism of renal injury involved with CLL/SLL, thereby improving our current therapeutic efforts.

\section{Abbreviations}

CLL: Chronic lymphocytic leukemia; SLL:Small Lymphocytic Lymphoma; MPGN: Membranoproliferative glomerulonephritis; LCPT: light chain proximal tubulopathy.

\section{Declarations}

Ethics approval and consent to participate 
The research was in compliance with the declaration of Helsinki and approved by the ethic committee of Peking University First Hospital.

\section{Informed consent statement}

All patients have signed an informed consent form on inclusion and at each follow-up assessment.

\section{Consent for publication}

Written informed consent was obtained from the patient for publication of the case report and any accompanying images.

\section{Availability of data and materials}

All data generated or analysed during this study are included in this published article.

\section{Competing interests}

All authors declare no conflict of interest.

\section{Funding}

This research was supported by grants from National Natural Science Foundation of China (No. 81470956). The funder had no role in the design of the study and collection, analysis, and interpretation of data and in writing the manuscript. The authors conducted this study independently.

\section{Authors' Contributions}

XiaoJuan Yu and Minghui Zhao contributed to patient diagnosis, management and clinical data analysis. Hui Wang, Xu Zhang and Suxia Wang contributed to patient pathological diagnosis, took and edit pathological pictures. Hui Wang and Suxia Wang wrote manuscript drafting, contributed to data analysis and interpretation. Suxia Wang and Minghui Zhao contributed to final review of manuscript.

\section{Acknowledgements}

Not Applicable.

\section{References}

1. Yang SM, Li JY, Gale RP, Huang XJ. The Mystery of Chronic Lymphocytic Leukemia (CLL): Why Is It Absent in Asians and What Does This Tell Us About Etiology, Pathogenesis and Biology? Blood Rev. 2015; 29: 205-213.

2. Hallek, M. Chronic lymphocytic leukemia: 2015 update on diagnosis, risk stratification, and treatment. Am J Hematol. 2015; 90: 446-460.

3. Wanchoo R, Ramirez CB, Barrientos J and Jhaveri KD. Renal involvement in chronic lymphocytic leukemia. Clinical Kidney Journal. $2018 ; 11: 670-680$.

4. Shanafelt TD, Rabe KG, Hanson CA, et al. Renal disease in patients with chronic lymphocytic leukemia (CLL). Blood. $2013 ; 122: 5302-5302$.

5. Strati P, Nasr SH, Leung N, et al. Renal complications in chronic lymphocytic leukemia and monoclonal B-cell lymphocytosis: the Mayo Clinic experience. Haematologica. 2015; 100: 1180-1188.

6. Poitou-Verkinder AL, Francois A, Drieux F, et al. The spectrum of kidney pathology in B-cell chronic lymphocytic leukemia/small lymphocytic lymphoma: A 25-Year Multicenter Experience. PLOS ONE. 2015; 510: e0119156.

7. Uprety D, Peterson A, Shah BK. Renal failure secondary to leukemic infiltration of kidneys in CLL-a case report and review of literature. Ann Hematol. 2013; 92:271-273.

8. Phillips JK, Bass PS, Majumdar G, Davies DR, Jones NF, Pearson TC. Renal failure caused by leukaemic infiltration in chronic lymphocytic leukaemia. J Clin Pathol. 1993; 46:1131-1133.

9. Ferreira AC, Brum S, Carvalho D, et al. Renal dysfunction due to leukemic infiltration of kidneys in a case of chronic lymphocytic leukemia. Hemodialysis International. 2010; 14:87-90.

10. Kamat AV, Goldsmith D, Donnell PO, Walt JVD, Robert Carr R. Renal Failure with Granulomatous Interstitial Nephritis and Diffuse Leukemic Renal Infiltration in Chronic Lymphocytic Leukemia. Renal Failure. 2007; 29:763-765.

11. Kiewe P, Tepel M, Loddenkemper C, et al. Extensive leukemic kidney infiltration with membranoproliferative glomerulonephritis in a patient with B-cell chronic lymphocytic leukemia. Ann Hematol. 2007; 86:691-692.

12. Hewamana S, Pepper C, Jenkins C, Rowntree C. Acute renal failure as the presenting feature of leukaemic infiltration in chronic lymphocytic leukaemia. Clin Exp Nephrol. 2009; 13:179-181.

13. Erten N, Saka B, Caliskan YK, Besisik S, Karan MA, Tascioglu C. Acute renal failure due to leukaemic infiltration in chronic lymphocytic leukaemia: case report. Int J Clin Pract Suppl. 2005; 147:53-55.

14. Muller-Hermelink HK, Montserrat E, Catovsky D, et al. Chronic lymphocytic leukemia/small lymphocytic lymphoma. WHO classification of tumours of hematopoietic and lymphoid tissues. Lyon. 2008; 180-182.

15. Swerdlow SH, Campo E, Pileri SA, et al. The 2016 revision of the World Health Organization classification of lymphoid neoplasms. Blood. 2016; 127: 23752390.

Page $7 / 11$ 
16. Li DY, Liu D, Wang SX, et al. Renal leukocyte chemotactic factor 2 (ALECT2)-associated amyloidosis in Chinese patients. Amyloid. 2020; $27: 134-141$.

17. Fermand JP, Bridoux F, Kyle RA, et al. How I treat monoclonal gammopathy of renal significance (MGRS). Blood. 2013; 122:3583-3590.

18. Lommatzsch SE, Bellizzi AM, Cathro HP, Rosner MH. Acute renal failure caused by renal infiltration by hematolymphoid malignancy. Ann Diagn Pathol. 2006; 10: 230-234.

19. Rizzo DJ, Chauzeix F, Trimoreau JB, et al. IgM peak independently predicts treatment-free survival in chronic lymphocytic leukemia and correlates with accumulation of adverse oncogenetic events. Leukemia. 2015; 29:337-345.

20. Xu W, Wang YH, Fan L, et al. Prognostic significance of serum immunoglobulin paraprotein in patients with chronic lymphocytic leukemia. Leukemia Research. 2011; 35:1060-1065.

21. Larsen CP, Bell JM, Harris AA, Messias NC, Wang YH, Walker PD. The morphologic spectrum and clinical significance of light chain proximal tubulopathy with and without crystal formation. Modern Pathology. 2011; 24:1462-1469.

22. M Ciccone, C Agostinelli, GM Rigolinet, et al. Proliferation centers in chronic lymphocytic leukemia: correlation with cytogenetic and clinicobiological features in consecutive patients analyzed on tissue microarrays. Leukemia. 2012; 26: 499-508.

23. Garces S, Khoury JD, Kanagal-Shamanna R, et al. Chronic lymphocytic leukemia with proliferation centers in bone marrow is associated with younger age at initial presentation, complex karyotype, and TP53 disruption. Hum Pathol. 2018; 82:215-231.

24. Gine E, Martinez A,Villamor N, et al. Expanded and highly active proliferation centers identify a histological subtype of chronic lymphocytic leukemia (accelerated chronic lymphocytic leukemia) with aggressive clinical behavior. Haematologica. 2010; 95:1526-1533.

25. Gibson SE, Leeman-Neill RJ, Jain S, Piao WH, Cieply KM, Swerdlow SH. Proliferation centres of chronic lymphocytic leukaemia/small lymphocytic lymphoma have enhanced expression of MYC protein: which does notresult from rearrangement or gain of the MYC gene. Br J Haematol. 2016; 175:173175.

26. Damle RN, Ghiotto F, Valetto A, et al. B-cell chronic lymphocytic leukemia cells express a surface membrane phenotype of activated: antigen-experienced B lymphocytes. Blood. 2002; 99: 4087-4093.

27. Gradowski JF, Sargent RL, Craig FE, et al. Chronic lymphocytic leukemia/small lymphocytic lymphoma with cyclin D1 positive proliferation centers do not have CCND1 translocations or gains and lack SOX11 expression. Am J Clin Pathol. 2012; 138:132-139.

28. Burger JA, Ghia P, Rosenwald A, Cappio FC. The microenvironment in mature B-cell malignancies: a target for new treatment strategies. Blood. 2009; 114: 3367-3375.

\section{Figures}




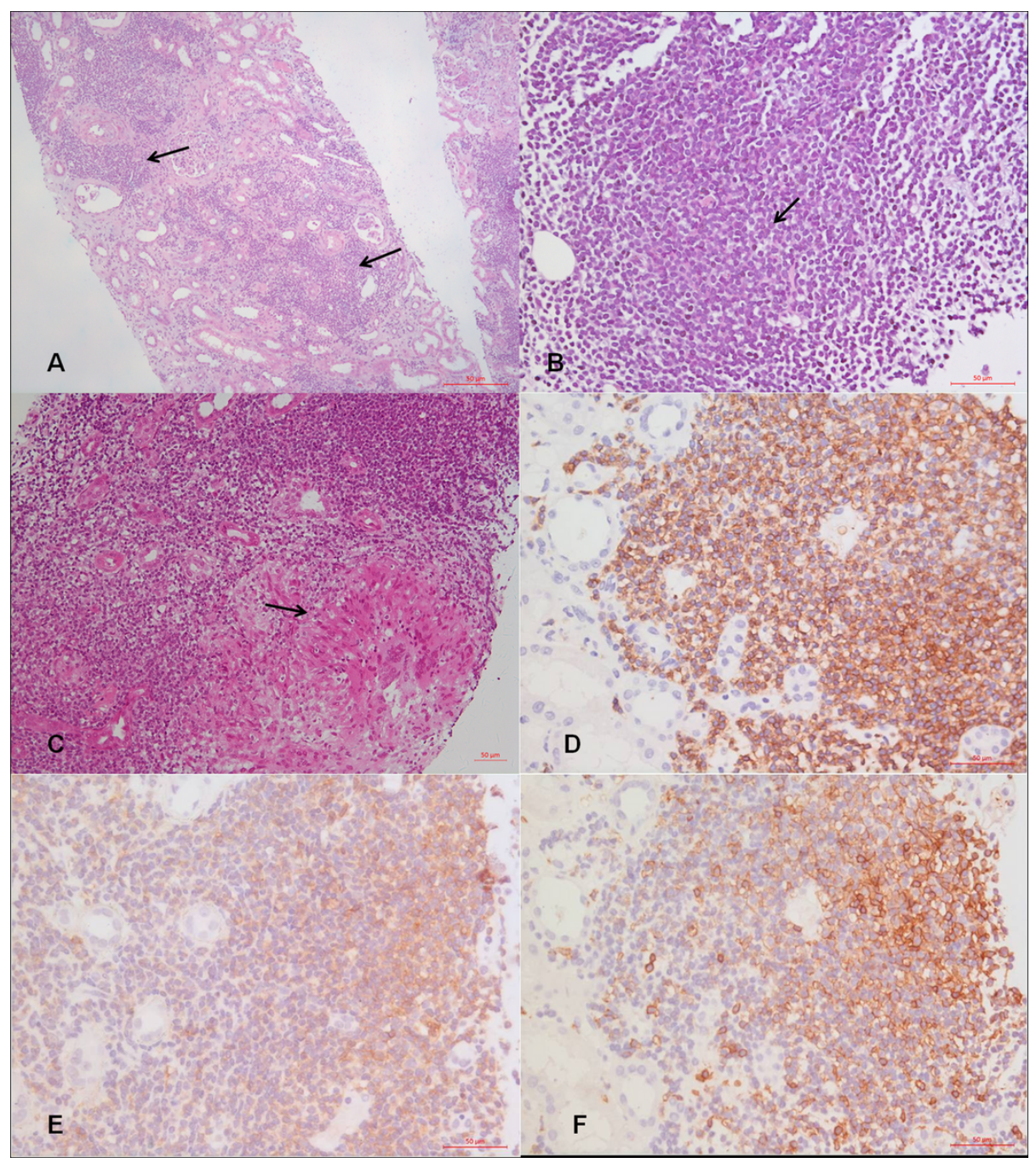

\section{Figure 1}

Representative light microscopic findings of renal biopsy. A. CLL cells infiltration was seen in the renal interstitium as indicated by arrows (HE, $\times 100)$. B. Vaguely nodular pattern was seen in the renal interstitium as indicated by the arrow $(\mathrm{HE}, \times 400)$. C. Interstitial gigantocellular granulomas were formed in the renal interstitium as indicated by the arrow $(\mathrm{HE}, \times 200)$. D. Infiltrating CLL cells stain positively for CD20 (Immunohistochemistry, $\times 200)$. E. Infiltrating CLL cells stain positively for CD5 (Immunohistochemistry, $\times 200$ ). F. Infiltrating CLL cells stain positively for CD23 (Immunohistochemistry, $\times 200)$. 


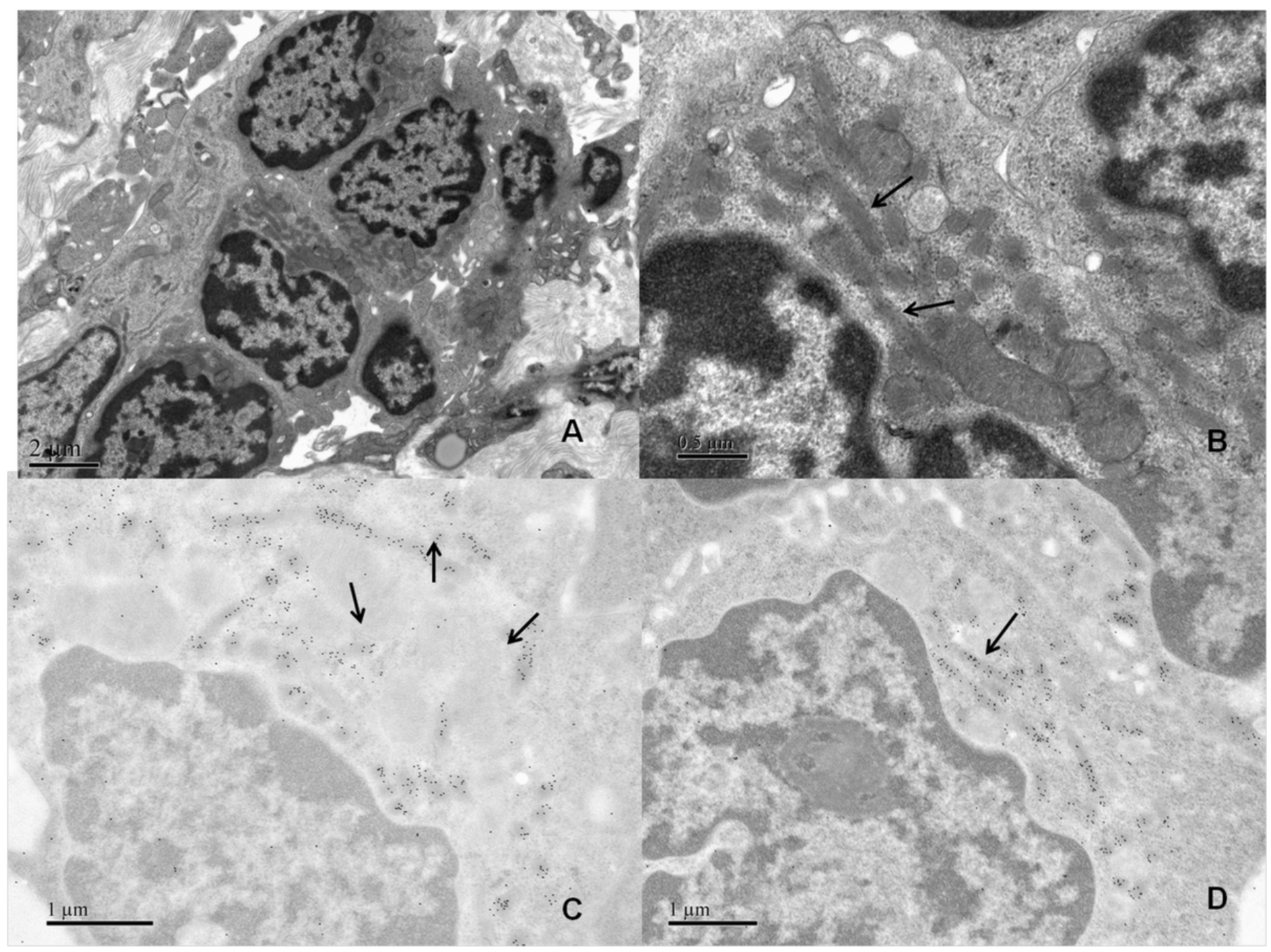

Figure 2

Representative electron microscopy findings of renal biopsy in case 6. A. Neoplastic cells infiltration was seen in the renal interstitium ( $\times 10000)$. B. Special cytoplasmic crystals characterized by fuzzy filament structure were found in infiltrating neoplastic cells as indicated by arrows ( $\times 40000)$. C. Intense IgG1 was detected in the crystalline structures of neoplastic cells as indicated by the arrow (Immunoelectron microscopy labelling, $\times 30000)$. D. Intense kappa was detected in the crystalline structures of neoplastic cells as indicated by the arrow. (Immunoelectron microscopy labelling, $\times 25000$ ). 


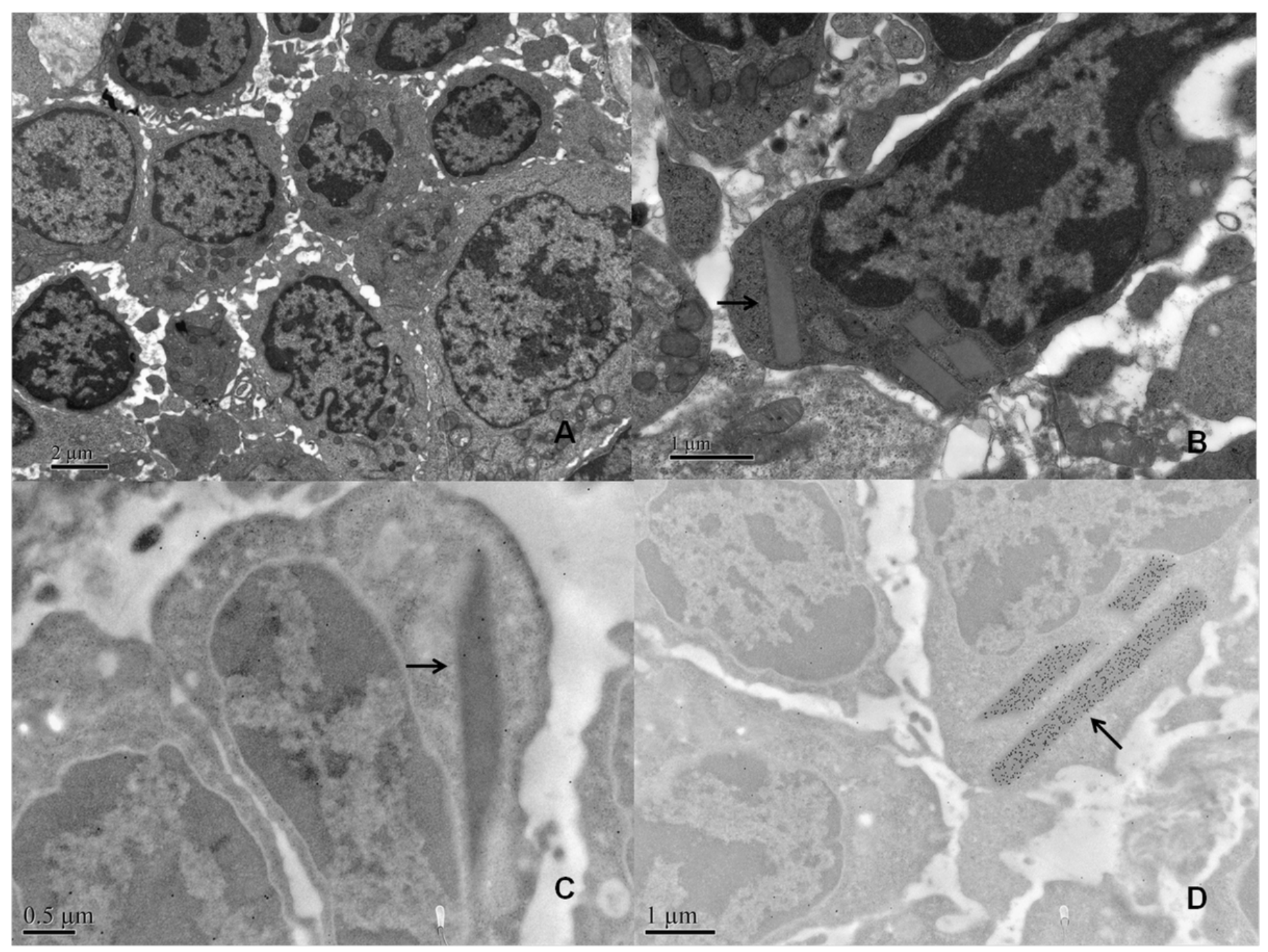

\section{Figure 3}

Representative electron microscopy findings of renal biopsy in case 2. A. Neoplastic cells infiltration was seen in the renal interstitium ( $\times 8000)$. B. Rhombic crystals were formed in infiltrating neoplastic cells as indicated the arrow $(\times 25000)$. C. Light kappa was not detected in neoplastic cells (Immunoelectron microscopy labelling, $\times 30000$ ). D. Intense light lamda was detected in the crystalline structures of neoplastic cells as indicated by the arrow (Immunoelectron microscopy labelling, $\times 20000$ ). 